\title{
Regional benthic food web structure on the Alaska Beaufort Sea shelf
}

\author{
Lauren M. Divine ${ }^{1, *}$, Katrin Iken $^{1}$, Bodil A. Bluhm ${ }^{1,2}$ \\ ${ }^{1}$ School of Fisheries and Ocean Sciences, University of Alaska Fairbanks, PO Box 757220, Fairbanks, Alaska 99775-7220, USA \\ ${ }^{2}$ Department of Arctic and Marine Biology, UiT-The Arctic University of Norway, 9037 Tromsø, Norway
}

\begin{abstract}
Trophic structure and resilience of regional benthic food webs were studied on the Alaska Beaufort Sea shelf across 3 geographic regions (east, central, and west) and 2 depth ranges (14 to $90 \mathrm{~m}$ [shallow] and 100 to $220 \mathrm{~m}$ [deep]). Carbon $\left(\delta^{13} \mathrm{C}\right)$ and nitrogen $\left(\delta^{15} \mathrm{~N}\right)$ isotope ratios were measured from water column and sediment particulate organic matter (POM) as markers of primary food sources and from common benthic invertebrate taxa. Isotopic niche space $\left(\delta^{13} \mathrm{C}-\right.$ $\delta^{15} \mathrm{~N}$ ) occupied by benthic taxa provided measures of community-wide trophic redundancy and separation. $\delta^{13} \mathrm{C}$ values of the water column and sediment POM were patchy but generally indicative of terrestrial input across the shelf, especially near the mouth of the Colville River $(<-25.5 \%$ ). Food web structures in the shallow and deep western Beaufort regions, however, reflected marine carbon inputs, with most consumers occupying intermediate trophic levels (TLs) and food webs of intermediate trophic redundancy and separation relative to the other regions. In the central shallow and east regions, the terrestrial carbon found in sediments was mirrored in consumer tissues. The central deep region contained the highest proportions of higher TL taxa, particularly within the predator feeding guild, possibly reflecting resource partitioning of a limited prey spectrum. The comparatively large isotopic niche space in the central deep region, with high trophic niche separation but low trophic redundancy, suggests that this region may be most vulnerable to perturbations. This study provides a valuable new understanding of benthic food web dynamics in the understudied Alaska Beaufort Sea region and represents a baseline for future comparison.
\end{abstract}

KEY WORDS: Benthos $\cdot$ Carbon · Feeding guild · Nitrogen · Stable isotope $\cdot$ Trophic structure

\section{INTRODUCTION}

Arctic benthic shelf communities can be hot spots of biomass, and contribute considerably to overall secondary production, carbon cycling, and remineralization of nutrients (Grebmeier 2012, Link et al. 2013). High benthic secondary production on icecovered Arctic shelves results from phytoplankton and sea ice algal production that are often not extensively grazed in the water column because zooplankton communities are still underdeveloped in the early spring when primary production occurs (Carroll \& Carroll 2003). Consequently, a large portion of organic carbon is deposited to the seafloor, effectively

${ }^{*}$ Corresponding author: lmdivine@alaska.edu coupling pelagic production to benthic invertebrate communities (Feder et al. 1994, Grebmeier et al. 2006, Grebmeier 2012). These benthic communities provide food for large invertebrates such as snow crabs Chionoecetes opilio (Kolts et al. 2013) and fishes (Atkinson \& Percy 1992) as well as large bottomfeeding marine mammals such as gray whales Eschrichtius robustus, walrus Odobenus rosmarus, and bearded seals Erignathus barbatus (Lowry et al. 2004, Dehn et al. 2007). Climate change-driven shifts in the timing and quantity of primary production available for benthic secondary production will likely have profound effects on ecosystem functioning and services (e.g. carbon sequestration, food web sup-

() The authors 2015. Open Access under Creative Commons by Attribution Licence. Use, distribution and reproduction are unrestricted. Authors and original publication must be credited. Publisher: Inter-Research · www.int-res.com 
port) of benthic communities. Specifically, changes in the timing of sea ice melt and spring phytoplankton production may critically influence the tight pelagicbenthic coupling of Arctic shelves (Hunt \& Stabeno 2002, Grebmeier 2012). Long-term shifts in macrobenthic community composition and carbon cycling attributed to the loss of sea ice and changes in primary production regimes have already been observed in the Bering and Chukchi seas (Grebmeier 2012). To assess the impacts of these shifts on benthic communities, numerous studies have addressed organic matter assimilation pathways in benthic food webs on Alaska's high Arctic shelves (e.g. Chukchi Sea: Iken et al. 2010, Feder et al. 2011, McTigue \& Dunton 2013; nearshore Beaufort Sea: Dunton et al. 1989, 2006, 2012). However, a large portion of the offshore Beaufort shelf food web remains relatively understudied in comparison with the above-mentioned regions of the Alaska Arctic.

The Alaska Beaufort shelf is a narrow $(\sim 80 \mathrm{~km}$ wide), nearly rectangular shelf situated between 2 advective shelves, the Chukchi shelf to the west and the Canadian Arctic Archipelago shelf to the east (Fig. 1; Dunton et al. 2006). Sea ice dynamics, local winds, and inflows from the oceanic and coastal boundaries result in complex hydrography and cross-shelf heterogeneity in physical characteristics (Pickart 2004, Dunton et al. 2006, Logerwell et al. 2011). Nutrient-rich, low-salinity waters originating in the Bering Sea flow northward along the eastern Chukchi Sea before diverting east around Point Barrow to enter the western Beaufort Sea and continuing eastward along the shelf break in a jet, delivering nutrients and resuspending particulate organic matter (POM) to the western portion of the shelf (Ashjian et al. 2005). In offshore western and central Beaufort regions, these Chukchi waters encounter flows in the opposite direction in the anti-cyclonic, oligotrophic Beaufort Gyre over the Canada Basin (Pickart 2004). POM is also supplied to Beaufort shelf seafloor communities through upwelling events along the shelf break and circulation associated with seafloor bathymetry near Barrow Canyon adjacent to the western Beaufort slope (Fig. 1; Okkonen et al. 2009). Over the past 2 decades, sea ice has been regularly retreating beyond the shelf break (Carmack \& Chapman 2003, Weingartner 2008), allowing wind-driven upwelling to become a frequent feature along the shelf break of the Beaufort Sea, potentially increasing the amount of nutrients supplied to the shelf (Tremblay et al. 2011, Pickart et al. 2013).

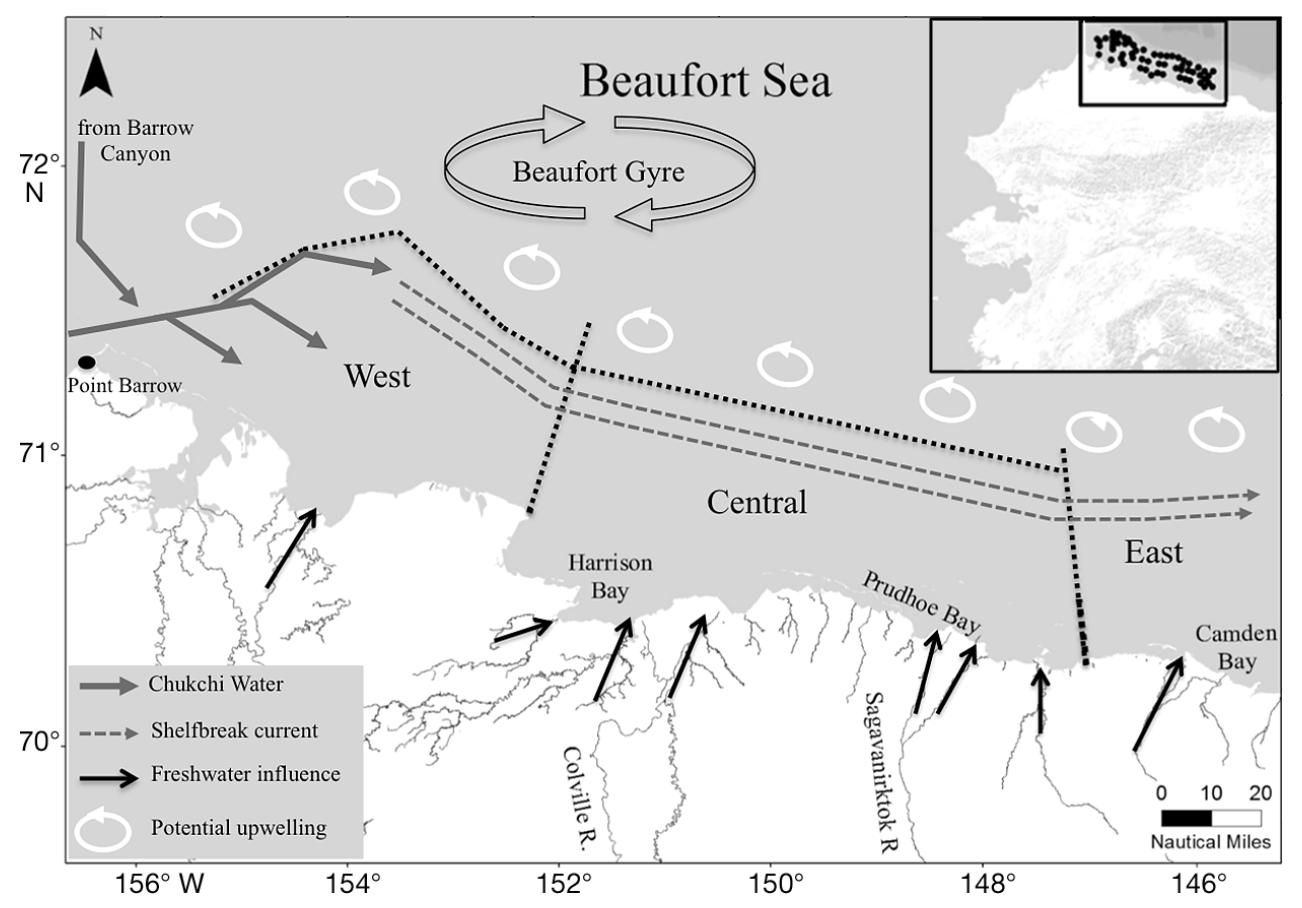

Fig. 1. Alaska Beaufort Sea shelf, from Point Barrow to Camden Bay, Alaska. Major water mass movements are denoted along the Beaufort shelf. Nutrient-rich, low-salinity waters from the Chukchi Sea enter the western Beaufort Sea at Point Barrow and are funneled through Barrow Canyon adjacent to the slope. In offshore western and central Beaufort regions, waters flow in the opposite direction in the clockwise, oligotrophic Beaufort Gyre over the Canada Basin. Upwelling events may occur along any portion of the shelf break during the open water period. Dark dotted lines outline study regions. Sampled stations are indicated in the inset map as black dots. 
Freshwater input also supplies organic matter to the Beaufort shelf region. The Colville and Mackenzie rivers together add nearly $350 \mathrm{~km}^{3}$ of freshwater runoff annually to the central and eastern portions of the Beaufort shelf (Macdonald et al. 2004). Maximum discharge from the larger Mackenzie River occurs over approximately $3 \mathrm{wk}$ in spring while nearshore waters are still ice covered (Macdonald et al. 2004). This discharge delivers more terrestrial carbon than all other Arctic rivers combined (Rachold et al. 2004), which settles into the sediments (Naidu 1974). Satellite images have captured the sediment plume from the Mackenzie extending over $400 \mathrm{~km}$ off the shelf (Macdonald et al. 1999). However, the westward extent of the Mackenzie outflow is variable over time, and allochthonous nutrient and terrestrial carbon input from the numerous smaller rivers can probably be as important, at least to nearshore (<20 m depth) Alaska Beaufort food webs (Dunton et al. 2006). Coastal erosion also contributes large amounts of terrestrially derived carbon to the Alaska portion of the Beaufort shelf (Goñi et al. 2013). Although the importance of terrestrial carbon subsidies, including those from the Mackenzie River, to nearshore benthic food webs of the Beaufort Sea has been established (e.g. Parsons et al. 1989, Dunton et al. 2006, 2012), the seaward and lateral extents of the terrestrial carbon supply to the Beaufort Sea shelf system are largely unknown.

Carbon isotopes $\left(\delta^{13} \mathrm{C}\right)$ are a useful marker of such terrestrial food sources: $\delta^{13} \mathrm{C}$ values more positive than $-25.5 \%$ o have been defined as marine derived (i.e. phytoplankton) and values more negative than $-25.5 \%$ as reflective of terrestrial carbon contributions in the nearshore Beaufort Sea (Dunton et al. 2012). Terrestrially derived organic matter is typically considered to be less labile, and thus less desirable as a primary food source for benthic consumers, than marine-derived organic matter (e.g. Dunton et al. 2006, 2012), although the role of bacteria in reworking terrestrial material into a usable form is largely unknown (Garneau et al. 2009). A declining west-to-east gradient in $\delta^{13} \mathrm{C}$ isotope values consistent with increasing terrestrial carbon inputs has been established on the Beaufort shelf, specifically in nearshore estuarine sediments (Naidu et al. 2000), zooplankton communities (Saupe et al. 1989), some western shallow benthic fauna (<50 m depth: Dunton et al. 1989, 2006, 2012), and bowhead whales Balaena mysticetus feeding in the region (Schell et al. 1989). However, much of the offshore region of the Beaufort shelf benthos remains undocumented regarding the degree of terrestrial carbon contributions and the effects on benthic food webs.
Similarly, nitrogen isotope $\left(\delta^{15} \mathrm{~N}\right)$ ratios can be used to estimate the trophic level (TL) of consumers relative to their food sources. Here, we define trophic structure as the relative numbers of taxa at different TLs. By this definition, we interpret a small range and low $\delta^{15} \mathrm{~N}$ values in consumer tissues within the benthic food web as tight pelagic-benthic coupling (Dunton et al. 2005, Iken et al. 2010). As water depth increases, however, biological and biogeochemical processes (e.g. microbial alteration, hydrolytic enzymatic activity) change the $\delta^{15} \mathrm{~N}$ of organic matter as it sinks to the benthos, and these processes have been suggested to explain water depth-dependent increases in POM and consumer tissue $\delta^{15} \mathrm{~N}$ values in several oceanic regions (Rau et al. 1991, Mintenbeck et al. 2007). In addition to depth-related trends, large-scale regional differences have been shown with lower $\delta^{15} \mathrm{~N}$ values of zooplankton and some benthic fauna in the Beaufort Sea relative to those in the Bering and Chukchi seas (Dunton 1985, Dunton et al. 1989). Some causes of these regional gradients may be different isotope fractionation processes related to temperature or variation in the isotopic composition of basal carbon and nitrogen sources (Dunton 1985, Dunton et al. 1989). Broad coverage of the understudied offshore Beaufort Sea shelf is necessary to fully elucidate these potential depth-dependent and geographical gradients as they relate to variability in benthic food web structure across the shelf.

Community-wide measures of trophic niche space in $\delta^{13} \mathrm{C}-\delta^{15} \mathrm{~N}$ space provide quantitative estimates of the vulnerability or resilience of a community to changes in trophic structure (Bearhop et al. 2004, Layman et al. 2007). Useful metrics in this context include trophic redundancy (degree of dietary overlap among taxa within a food web in $\delta^{13} \mathrm{C}-\delta^{15} \mathrm{~N}$ space), trophic separation (degree of dietary separation among taxa within a food web, also termed trophic diversity; Layman et al. 2007), and community niche space (total area [TA] occupied by all taxa within a standardized range of $\delta^{13} \mathrm{C}$ and $\delta^{15} \mathrm{~N}$ values; see details in Layman et al. 2007). In a food web with low trophic redundancy and high trophic separation, removal of 1 species from the system (e.g. by climate change, fisheries removal, competitive interactions, or stochastic events) could leave a vacant niche that could not be easily occupied by another consumer, possibly leading to instability within the food web (Layman et al. 2007). In contrast, in a system with high trophic redundancy and low trophic separation, other consumers occupying a similar trophic role could likely compensate for the role of the removed species. While there are limits to these metrics as 
absolute measures (Hoeinghaus \& Zeug 2008), they are useful for relative comparisons among habitats such as regions across the Beaufort Sea shelf.

The purpose of this study was to characterize benthic food web structure on the Alaska Beaufort Sea shelf using stable isotope analysis. Specifically, we tested the following hypotheses: (1) $\delta^{13} \mathrm{C}$ and $\delta^{15} \mathrm{~N}$ isotopic values of water column and bulk sediment POM vary along a west-to-east gradient on the Beaufort Sea shelf, with lower $\delta^{13} \mathrm{C}$ and $\delta^{15} \mathrm{~N}$ values occurring in the eastern Beaufort Sea because of closer proximity to the Mackenzie River outflow. (2) $\delta^{13} \mathrm{C}$ values of water column and bulk sediment POM increase along an onshore-offshore gradient, and $\delta^{15} \mathrm{~N}$ values of bulk sediment POM increase with water depth (offshore). Higher POM $\delta^{13} \mathrm{C}$ values occur in offshore regions because of greater distance to terrestrial influx (Schell et al. 1998) and in both isotopes because of longer biogeochemical transformation as materials sink to the greater depth at offshore sites (Mintenbeck et al. 2007, France \& Peters 2013). As sinking and transformation do not apply to surface water column POM, we did not hypothesize an offshore increase in surface water column POM $\delta^{15} \mathrm{~N}$ values. (3) Food web length increases from west to east, reflecting a decrease in fresh marine production from west to east and thus a higher dependence on refractory, terrestrial food sources in the east. (4) Overall food web structure varies among regions, with TLs occupied by a given feeding guild being higher in the east compared with those in the west. (5) The trophic redundancy of consumers decreases and trophic separation increases from west to east, due to weaker pelagic-benthic coupling and subsequently more niche specialization, in the eastern Beaufort Sea in response to the limited labile food sources available.

\section{MATERIALS AND METHODS}

\section{Study area}

Field sampling was conducted at 64 stations in the Alaska Beaufort Sea (Fig. 2) from 17 August to 2 September 2011 onboard the R/V 'Norseman II' within the framework of the Bureau of Ocean Energy Management BeauFish program. Sampling stations were aligned along the shelf between 145 and $156^{\circ} \mathrm{W}$ at water depths between 14 and $220 \mathrm{~m}$ (Table S1 in the Supplement at www.int-res.com/articles/suppl/ m531p015_supp.pdf). As we were interested in large-

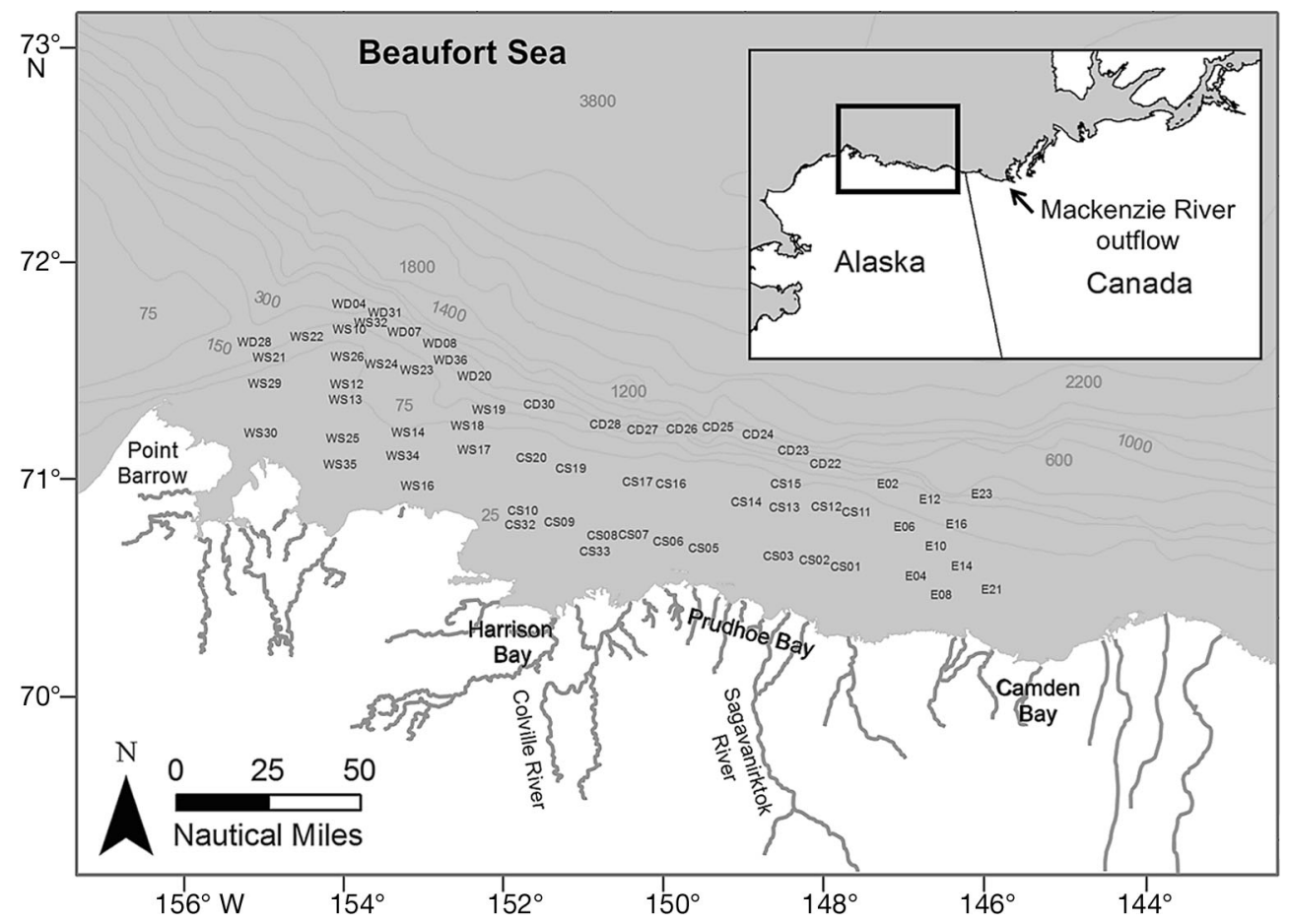

Fig. 2. Sampling stations, indicated by numbers, in the Alaska Beaufort Sea (see Table S1 in the Supplement at www.int-res. com/articles/suppl/m531p015_supp.pdf). The location of the Mackenzie River outflow is indicated in the smaller map inset, and other rivers are indicated on the map is dark gray. Depth contours are shown in light gray 
scale, shelf-wide trophic patterns, we assigned stations to regions (west, central, east; Fig. 2) based on a combination of previous sampling areas that were focused on groundfish surveys (Frost \& Lowry 1983, Rand \& Logerwell 2011), oceanographic conditions, and based on breaks in the sampling scheme. West stations (bounding box: 70.10 to $70.90^{\circ} \mathrm{N}, 144.95$ to $147.07^{\circ} \mathrm{W}$ ) included an area that was sampled in 2008 for bottom communities (Logerwell et al. 2011) and is strongly influenced by water masses originating in the Bering and Chukchi seas, particularly along the shelf break (Okkonen et al. 2011, Pickart et al. 2013). The boundaries for the central (70.50 to $71.30^{\circ} \mathrm{N}, 147.28$ to $\left.151.34^{\circ} \mathrm{W}\right)$ and east (71.16 to $71.81^{\circ} \mathrm{N}, 151.98$ to $154.98^{\circ} \mathrm{W}$ ) regions were chosen to separate out the possibly stronger influence of the Mackenzie River in the eastern portion of the Beaufort shelf (Macdonald et al. 2004). The central and west regions were further divided into depth strata based on bathymetry, shallow ( $\leq 90 \mathrm{~m})$ and deep $(\geq 100 \mathrm{~m})$, based on breaks in station coverage and the presence of the shelfbreak jet (Fig. 1). The east region contained only 1 deep station (depth of $127 \mathrm{~m}$ ), which was combined with the shallower stations; consequently, the east represents only 1 depth zone. All regions (e.g. central shallow) refer to the US portion of the Beaufort shelf (see Fig. 2). The physical environment of each station was characterized by bottom water temperature and conductivity (salinity) at every station $(\mathrm{n}=64)$ within $\sim 5 \mathrm{~m}$ of the seafloor using a SeaBird 25 CTD rosette with an integrated SBE 55 Eco-Water sampler. All CTD data were processed by S. Danielson (University of Alaska Fairbanks). Spearman's rank correlations were used to determine the relationship between environmental data (bottom temperature and salinity, latitude/ longitude, water depth) and regional water column and sediment POM $\delta^{13} \mathrm{C}$ and $\delta^{15} \mathrm{~N}$ stable isotope ratios (see 'Stable isotope sample and data analysis') to assess if patterns in isotope ratios were related to environmental parameters.

\section{Isotope sample collection and preparation}

Water column POM samples were collected within the upper $\sim 10$ to $20 \mathrm{~m}$, below the surface freshwater lens, to represent the pelagic food source present at the time of sampling. Water column POM was collected from 3 water samples per station taken from Niskin bottles attached to the CTD rosette. While not true replicates, averaging multiple samples from 1 station created a more reliable isotopic mean per sta- tion from this heterogeneous POM source than a single sample. Water samples were filtered through a pre-combusted $25 \mathrm{~mm}$ diameter GF/F filter, and visible swimmers were removed. Filters were fumed with saturated $\mathrm{HCl}$ vapors for $24 \mathrm{~h}$ and subsequently dried at $60^{\circ} \mathrm{C}$ for $24 \mathrm{~h}$ before isotope analysis (see Iken et al. 2010). Bulk sediment POM ( $\mathrm{n}=1$ per station) was collected from the top $1 \mathrm{~cm}$ of an undisturbed van Veen grab sample $\left(0.1 \mathrm{~m}^{2}\right)$ into a sterile plastic bag and stored at $-20^{\circ} \mathrm{C}$ until processing. In the home laboratory, sediments were thawed, and each sample was mixed thoroughly. Approximately $1 \mathrm{ml}$ of sediment was treated with $6 \mathrm{~N} \mathrm{HCl}$ until bubbling ceased, after which samples were rinsed with distilled water until $\mathrm{pH}$ was neutral; they were then freeze dried before analysis (modified after Thornton \& McManus 1994). Water column and sediment POM samples were collected at every station and then averaged among stations within each region for mean regional POM values.

Epifauna were collected using a plumb staff beam trawl (2.26 m opening, $7 \mathrm{~mm}$ net mesh, $4 \mathrm{~mm}$ codend mesh). Benthic infauna were collected from trawl hauls and van Veen grabs that were sieved over $1 \mathrm{~mm}$ mesh. Van Veen grabs were not quantitatively sampled for infauna; hence, no quantitative community data were available. Trawls were quantitatively sampled for epibenthic community structure but at a coarser taxonomic level than that used for this food web study. Therefore, benthic invertebrate taxa that were either abundant at any sampled station or seen repeatedly at multiple stations within a region were collected on the regional level for food web analysis. Because of analytical limitations, only those benthic taxa that were well represented at the regional level were collected, i.e. rare taxa were not included. Sampling effort in terms of representative taxa per region was similar for all regions, and collections occurred at all stations within each region until all prominent taxa of the regional benthic communities were collected (based on qualitative observations of abundance for each taxa collected). Thus, the collection of benthic taxa for each region was considered representative of those taxa contributing most to benthic abundance and biomass. Some of those taxa were the same among regions, while others were characteristic only for particular regions. Within each region, 3 to 5 individuals of common epibenthic and infaunal invertebrate taxa were collected and sorted to species or practical higher taxon level for stable isotope analysis. Taxonomic identifications were conducted by the authors with support of the taxonomic experts listed in the 'Acknowledgements'. Taxonomic names 
were standardized to the World Register of Marine Species (www.marinespecies.org). Taxa were divided into 5 feeding guilds based on published information: predator, predator/scavenger, suspension, surface deposit, and subsurface deposit feeders (Fauchald \& Jumars 1979, Feder et al. 1994, 2005, Iken et al. 2010, Appeltans et al. 2012). Individuals were subsampled for muscle or body wall when muscle tissue could not be distinguished to represent a tissue with slow turnover and long-term nitrogen integration (Kaufman et al. 2008, Weems et al. 2012). Whole organisms were used when tissue samples did not yield sufficient mass for isotope analysis (e.g. small amphipods). Samples containing carbonate were treated with $1 \mathrm{~N}$ $\mathrm{HCl}$ until bubbling ceased, rinsed with distilled water, and dried at $60^{\circ} \mathrm{C}$ for $24 \mathrm{~h}$. Lipid content of all tissue samples was removed with repeated use of a 2:1 ratio of chloroform:methanol because organisms may vary in their concentrations of isotopically lighter lipids (e.g. Sholto-Douglas et al. 1991). Tissue samples were then re-dried at $60^{\circ} \mathrm{C}$ for $24 \mathrm{~h}$.

\section{Stable isotope sample and data analysis}

Samples were analyzed at the Alaska Stable Isotope Facility at the University of Alaska Fairbanks on a Thermo Finnigan Delta isotope ratio mass spectrometer with Vienna PDB and atmospheric $\mathrm{N}_{2}$ as standards for carbon and nitrogen, respectively. Sample isotopic ratios were expressed in the conventional $\delta$ notation as parts per thousand (\%) according to the following equation:

$$
\delta X=\left[\left(R_{\text {sample }} / R_{\text {standard }}\right)-1\right] \times 1000
$$

where $X$ is ${ }^{13} \mathrm{C}$ or ${ }^{15} \mathrm{~N}$ of the sample, and $R$ is the corresponding ratio ${ }^{13} \mathrm{C} /{ }^{12} \mathrm{C}$ or ${ }^{15} \mathrm{~N} /{ }^{14} \mathrm{~N}$. Instrument error was $<0.2 \%$ for both $\delta^{13} \mathrm{C}$ and $\delta^{15} \mathrm{~N}$ values.

Isotopic values for water column POM were compared among regions using the non-parametric Kruskal-Wallis test $(\alpha=0.05)$ based on individual station means in each region, followed by Steel-Dwass post hoc comparisons because these data violated the parametric assumptions of normality. Isotope values for surface sediment POM adhered to parametric assumptions and were compared using analysis of variance (ANOVA, $\alpha=0.05$ ) followed by Tukey's post hoc test. Additionally, isotope ratios for water column POM and sediment POM were compared across stations within each region (paired-sample $t$-test, $\alpha=0.05$ ).

The TLs of consumers $\left(\mathrm{TL}_{\mathrm{c}}\right)$, also referred to as trophic positions (Vander Zanden et al. 1997), were determined for each region using the equation:

$$
\mathrm{TL}_{\mathrm{c}}=\left(\delta^{15} \mathrm{~N}_{\text {consumer }}-\delta^{15} \mathrm{~N}_{\text {sediment POM }}\right) / 3.4+1
$$

where 3.4 is the assumed mean enrichment in $\delta^{15} \mathrm{~N}$ between successive discrete TLs in marine environments (Vander Zanden \& Rasmussen 2001, Post 2002). We make a distinction between the 2 terms used for food web comparisons, $\mathrm{TL}_{\mathrm{c}}$ and $\mathrm{TL}$, to separate the calculated trophic position of an individual taxon (e.g. $\mathrm{TL}_{\mathrm{c}}=3.3$; a continuous measure) from the aggregation of all taxa occupying a discrete TL (e.g. TL3; a categorical measure). Mean $\mathrm{TL}_{\mathrm{c}}$ in the 5 feeding guilds described above met parametric assumptions and were compared among regions using ANOVA $(\alpha=0.05)$ followed by Tukey's post hoc test. Both water column and sediment POM represent mixtures of sources, including phytoplankton, bacteria, zooplankton carcasses and fecal pellets, and other particulate matter, with large temporal and spatial variation due to biogeochemical processes and turnover times (Cabana \& Rasmussen 1996, Tamelander et al. 2006, Sampei et al. 2009). Sediment POM (set as TL $=1$ ) was chosen as a baseline for all TL calculations because it represents a longerterm (i.e. weeks to months) measure of the organic matter available to consumers than water column POM and may better represent the carbon and nitrogen pool in benthic food webs (Cooper et al. 2013). We acknowledge that an unknown amount of microbial processing may render sediment POM at a higher TL than TL1, which we assigned to this source (Baird \& Ulanowicz 1989). Water column and sediment POM $\delta^{13} \mathrm{C}$ and $\delta^{15} \mathrm{~N}$ values were plotted in ArcGIS (version 10.1; ESRI 2011) by creating triangulated irregular networks (TIN) from vector-based nodes representing station mean values. The TINs are based on an algorithm that determines which points are most necessary to create an accurate representation of these data (ESRI 2011). Longitude and latitude represented the $x$ - and $y$-axes, respectively, and either water column or sediment POM $\delta^{13} \mathrm{C}$ or $\delta^{15} \mathrm{~N}$ represented the $z$-axis for each plot.

Benthic consumers in each region were plotted in $\delta^{13} \mathrm{C}-\delta^{15} \mathrm{~N}$ bi-plot space using the convex hull function in MATLAB V. 7.10.0 (release date 2010; The MathWorks Inc., Natick, MA), and all metrics discussed below were calculated using this software. Regional convex hull area was used to compare trophic niche space occupied by benthic communities among regions using several measures of regional trophic structure (Layman et al. 2007). Although this method cannot be used to infer absolute trophic niche characteristics, it is useful for comparative purposes (Hoeinghaus \& Zeug 2008). The trophic niche 
space occupied by the sampled benthic community in each region was calculated as the percentage of regional TA compared with a standardized area of the plot. In addition, mean distance to the centroid (CD) and mean nearest-neighbor distances (NNDs) were calculated for taxa in each region from the $\delta^{13} \mathrm{C}-\delta^{15} \mathrm{~N}$ bi-plots as measures of trophic separation and trophic redundancy, respectively (Layman et al. 2007). Mean CD was calculated as the mean of the Euclidean distances of all individual taxa to the mean $\delta^{13} \mathrm{C}$ and $\delta^{15} \mathrm{~N}$ value of all taxa within the region, and larger mean $C D$ values indicate higher trophic separation (Layman et al. 2007). The mean NND is the mean of all individual Euclidean distances of each taxon to their nearest neighbor in $\delta^{13} \mathrm{C}-\delta^{15} \mathrm{~N}$ bi-plot space, and smaller NND values indicate higher trophic redundancy.

\section{RESULTS}

\section{Environmental drivers}

None of the environmental drivers (bottom temperature and salinity, latitude/longitude, water depth) were significantly correlated with regional water column and sediment POM $\delta^{13} \mathrm{C}$ and $\delta^{15} \mathrm{~N}$ stable isotope ratios $(\rho<0.23$ and $p>0.05$ for all).

Hypothesis 1: $\delta^{13} \mathrm{C}$ and $\delta^{15} \mathrm{~N}$ isotopic values of water column and sediment POM food sources vary along a west-to-east gradient on the Beaufort Sea shelf

There was no consistent longitudinal gradient of regional water column or sediment POM $\delta^{13} \mathrm{C}$ or $\delta^{15} \mathrm{~N}$ values (Table 1 ; Figs. $3 \& 4$ ). Contrary to our hypothesis, mean regional water column POM $\delta^{13} \mathrm{C}$ values were highest in the central shallow region (Table 1), which was significantly enriched in ${ }^{13} \mathrm{C}$ compared with all other regions (Wilcoxon signed rank, p < 0.001), except the east (Fig. 3a). Additionally, the overall ranges of regional POM $\delta^{13} \mathrm{C}$ values were essentially identical for water column and sediment ( -26.2 to $-20.7 \%$ and -26.4 to $-20.7 \%$, respectively). Mean sediment $\delta^{13} \mathrm{C}$ POM values were either similar or slightly lower within each region relative to mean water column POM $\delta^{13} \mathrm{C}$, except in the central shallow, where sediment POM $\delta^{13} \mathrm{C}$ values were significantly lower compared with the overlying water column POM (Wilcoxon signed rank, p < 0.001). The $\delta^{13} \mathrm{C}$ of sediment POM was largely homogeneous among the west and central regions but higher in a localized portion in the far eastern part of the study area (Fig. 3b). Within the central shallow region, stations located near the Colville River delta had the lowest sediment $\delta^{13} \mathrm{C}$ values (range: -26.4 to $-25.6 \%$; Fig. 3b).

Similar to water column and sediment $\delta^{13} \mathrm{C}$ POM results, mean water column $\delta^{15} \mathrm{~N}$ values were similar across all regions (Kruskal-Wallis test, $\mathrm{p}>0.05$ ) but ranged widely among individual stations (from 1.2 to

Table 1. Mean $\delta^{13} \mathrm{C}$ and $\delta^{15} \mathrm{~N}$ isotope values $( \pm 1 \mathrm{SD})$ for bulk sediment particulate organic matter (POM) (baseline food source) and 5 consumer feeding guilds. TL: trophic level; PRED: predator; PS: predator/scavenger; SF: suspension feeder; SDF: surface deposit feeder; SSDF: subsurface deposit feeder

\begin{tabular}{|c|c|c|c|}
\hline $\begin{array}{l}\text { Region/ } \\
\text { feeding guild }\end{array}$ & $\delta^{13} \mathrm{C} \pm 1 \mathrm{SD}$ & $\delta^{15} \mathrm{~N} \pm 1 \mathrm{SD}$ & $\begin{array}{c}\text { Mean TL } \\
\pm 1 \mathrm{SD}\end{array}$ \\
\hline \multicolumn{4}{|l|}{ West deep } \\
\hline Water column POM & $-25.3 \pm 0.5$ & $6.5 \pm 1.2$ & \\
\hline Sediment POM & $-25.1 \pm 0.5$ & $4.8 \pm 1.7$ & \\
\hline PRED & $-18.8 \pm 1.6$ & $14.5 \pm 2.4$ & $3.9 \pm 0.6$ \\
\hline PS & $-18.5 \pm 1.8$ & $15.2 \pm 2.6$ & $4.1 \pm 0.8$ \\
\hline $\mathrm{SF}$ & $-19.0 \pm 1.0$ & $11.6 \pm 2.2$ & $3.0 \pm 0.6$ \\
\hline SDF & $-18.2 \pm 0.7$ & $12.0 \pm 1.6$ & $3.1 \pm 0.5$ \\
\hline SSDF & $-18.2 \pm 1.5$ & $10.9 \pm 4.0$ & $2.8 \pm 1.2$ \\
\hline \multicolumn{4}{|l|}{ West shallow } \\
\hline Water column POM & $-24.3 \pm 0.8$ & $5.3 \pm 0.9$ & \\
\hline Sediment POM & $-25.3 \pm 0.4$ & $4.2 \pm 0.4$ & \\
\hline PRED & $-18.5 \pm 1.4$ & $14.1 \pm 1.9$ & $3.9 \pm 0.5$ \\
\hline PS & $-19.4 \pm 1.3$ & $13.8 \pm 2.0$ & $3.8 \pm 0.6$ \\
\hline $\mathrm{SF}$ & $-20.0 \pm 1.3$ & $11.0 \pm 2.6$ & $3.0 \pm 0.8$ \\
\hline SDF & $-18.6 \pm 2.3$ & $11.5 \pm 1.7$ & $3.2 \pm 0.5$ \\
\hline SSDF & $-19.2 \pm 1.5$ & $10.5 \pm 2.6$ & $2.8 \pm 0.8$ \\
\hline \multicolumn{4}{|l|}{ Central deep } \\
\hline Water column POM & $-24.9 \pm 0.4$ & $5.2 \pm 1.0$ & \\
\hline Sediment POM & $-25.0 \pm 0.4$ & $4.8 \pm 0.6$ & \\
\hline PRED & $-18.5 \pm 0.7$ & $15.7 \pm 1.2$ & $4.2 \pm 0.7$ \\
\hline PS & $-19.4 \pm 3.1$ & $14.1 \pm 3.2$ & $3.7 \pm 0.9$ \\
\hline $\mathrm{SF}$ & $-20.0 \pm 0.9$ & $12.4 \pm 3.5$ & $3.2 \pm 1.0$ \\
\hline SDF & $-19.1 \pm 1.9$ & $12.5 \pm 0.9$ & $3.3 \pm 0.3$ \\
\hline SSDF & $-19.4 \pm 2.0$ & $10.4 \pm 3.1$ & $2.6 \pm 0.9$ \\
\hline \multicolumn{4}{|l|}{ Central shallow } \\
\hline Water column POM & $-23.4 \pm 1.1$ & $5.6 \pm 1.1$ & \\
\hline Sediment POM & $-25.5 \pm 0.4$ & $3.4 \pm 1.1$ & \\
\hline PRED & $-21.0 \pm 3.4$ & $11.7 \pm 1.6$ & $3.4 \pm 0.5$ \\
\hline PS & $-20.2 \pm 1.4$ & $12.8 \pm 1.8$ & $3.8 \pm 0.5$ \\
\hline $\mathrm{SF}$ & $-22.3 \pm 2.1$ & $8.5 \pm 1.9$ & $2.5 \pm 0.6$ \\
\hline SDF & $-20.2 \pm 1.0$ & $9.9 \pm 1.7$ & $2.9 \pm 0.5$ \\
\hline SSDF & $-20.4 \pm 1.2$ & $9.4 \pm 1.4$ & $2.8 \pm 0.4$ \\
\hline \multicolumn{4}{|l|}{ East } \\
\hline Water column POM & $-24.2 \pm 0.4$ & $5.7 \pm 0.7$ & \\
\hline Sediment POM & $-24.3 \pm 0.3$ & $4.4 \pm 1.2$ & \\
\hline PRED & $-20.43 \pm 1.3$ & $12.6 \pm 2.6$ & $3.4 \pm 0.8$ \\
\hline PS & $-20.9 \pm 1.4$ & $12.0 \pm 2.0$ & $3.2 \pm 0.6$ \\
\hline $\mathrm{SF}$ & $-21.7 \pm 0.7$ & $10.4 \pm 3.0$ & $2.8 \pm 0.9$ \\
\hline SDF & $-20.8 \pm 1.0$ & $10.1 \pm 1.6$ & $2.7 \pm 0.5$ \\
\hline SSDF & $-20.6 \pm 0.5$ & $9.2 \pm 1.5$ & $2.4 \pm 0.4$ \\
\hline
\end{tabular}



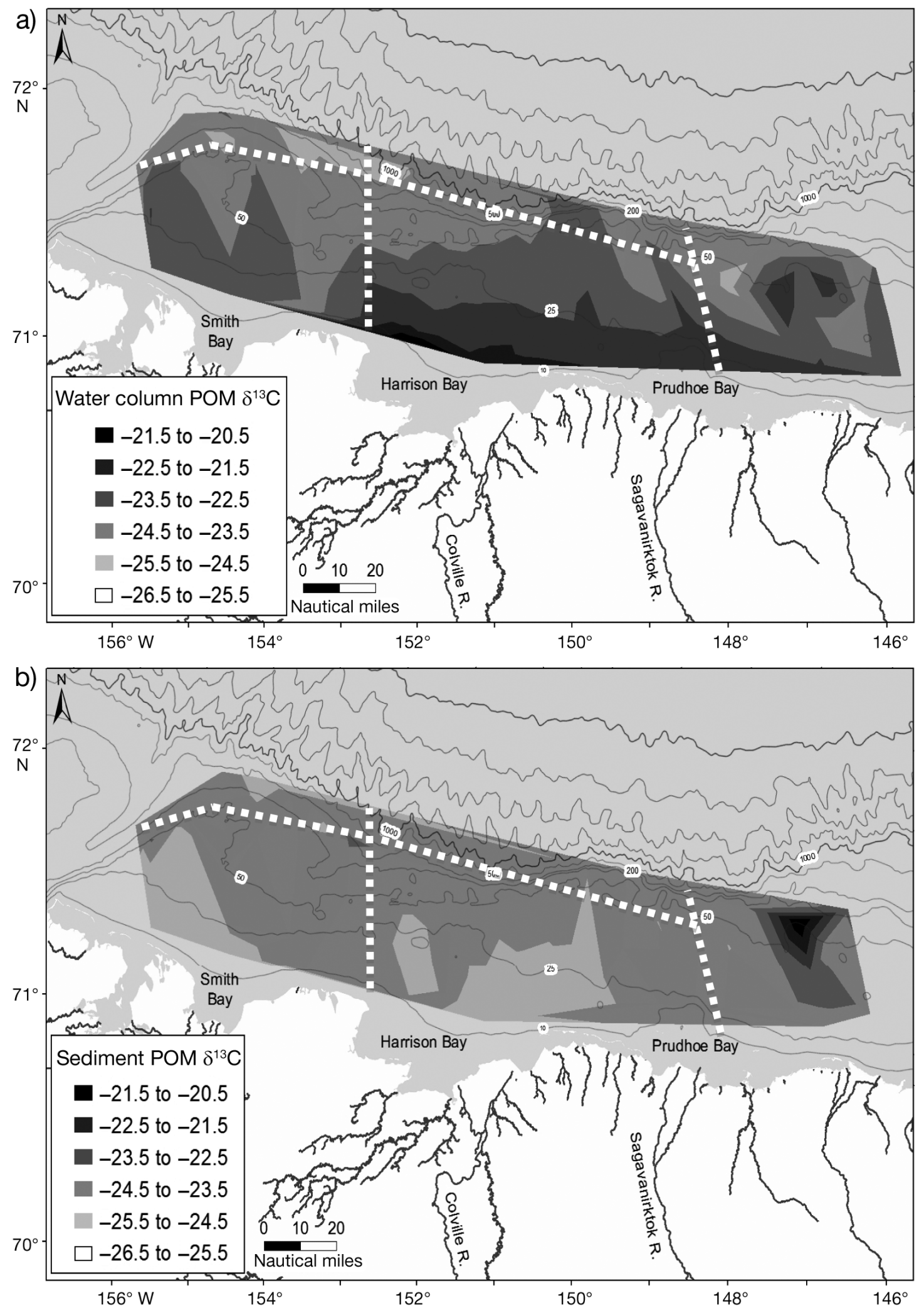

Fig. 3. Distribution of $\delta^{13} \mathrm{C}$ (\%; relative to Vienna PDB) in (a) water column particulate organic matter (POM) and (b) surface sediment POM of the Alaska Beaufort Sea shelf. Region boundaries are denoted by the white dashed lines. Gray lines and white numbers refer to depth contours (m) 

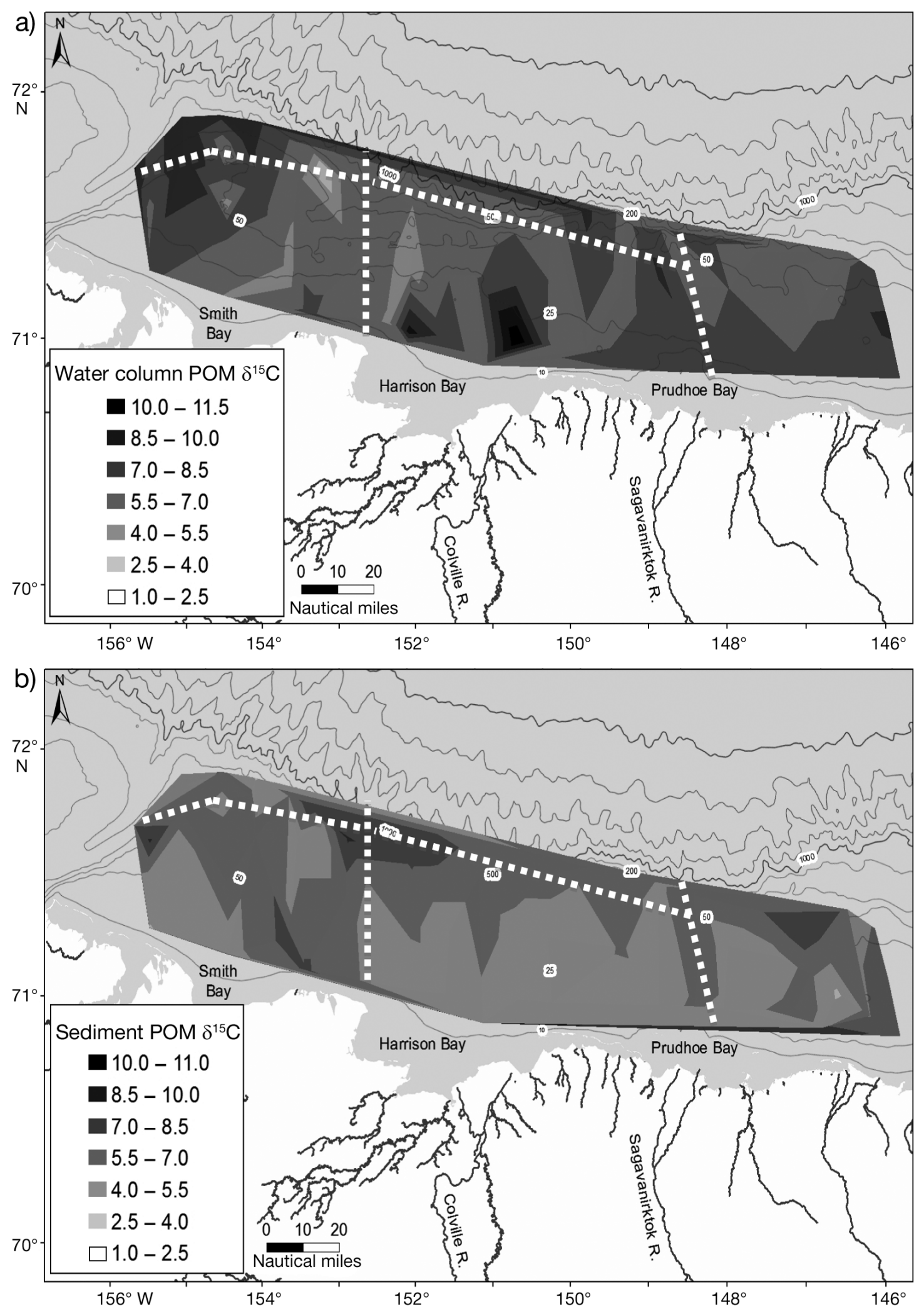

Fig. 4. Distribution of $\delta^{15} \mathrm{~N}\left(\%\right.$; relative to $\mathrm{N}_{\text {air }}$ ) in (a) water column particulate organic matter (POM) and (b) sediment POM of the Alaska Beaufort Sea shelf. Regions are denoted by the white dashed lines. Gray lines and white numbers refer to depth contours (m) 
11.2\%; Fig. 4a). The highest water column POM $\delta^{15} \mathrm{~N}$ values were observed in the west deep $(6.5 \%$ o \pm 1.2 $\mathrm{SD}$; Table 1). All regions had at least slightly lower sediment POM $\delta^{15} \mathrm{~N}$ values compared with the respective overlying water column POM $\delta^{15} \mathrm{~N}$ values. Comparing sediment POM $\delta^{15} \mathrm{~N}$ across regions, the central shallow was significantly lower in sediment $\delta^{15} \mathrm{~N}$ compared with all other regions (ANOVA, $\mathrm{p}<$ 0.001), except the east (Fig. 4b).

Hypothesis 2: $\delta^{13} \mathrm{C}$ values of water column and sediment POM increase along an onshore-offshore gradient, and $\delta^{15} \mathrm{~N}$ values of sediment POM increase with depth

There were no onshore-offshore trends in enrichment of mean regional water column or sediment POM $\delta^{13} \mathrm{C}$ values (Wilcoxon signed rank test, $\mathrm{p}>$ 0.05 for all regions; Table 1, Fig. 3a,b). In contrast to our hypothesis, offshore stations were either not different or slightly lower in water column and sediment POM $\delta^{13} \mathrm{C}$ compared with onshore stations (Fig. 3a,b). However, within the central shallow region, a distinct onshore-offshore gradient was apparent in water column POM $\delta^{13} \mathrm{C}$ values, with highest $\delta^{13} \mathrm{C}$ at stations located closest to the Colville River and progressively lower values with increasing distance from the shoreline (Fig. 3a). This pattern is masked when stations are pooled for a single regional mean.
In the water column, $\delta^{15} \mathrm{~N}$ was highest along the shelf break in the northwestern west region and showed a local peak just offshore of the Colville Delta (Fig. 4a). Enrichment of ${ }^{15} \mathrm{~N}$ in sediment POM was expected from shallow to deep sites because ${ }^{14} \mathrm{~N}$ should be preferentially lost in biological processing as materials sink to greater depths (Parsons et al. 1989). Central and west deep regions were indeed slightly higher in mean sediment $\delta^{15} \mathrm{~N}$ when compared with their shallower counterparts (Fig. 4b), with the central deep region being significantly higher than the central shallow (Tukey's post hoc test, $\mathrm{p}=0.001$ ).

Hypothesis 3: Food web length increases from west to east

Consumers covered a wide range of isotopic values and $\mathrm{TL}_{\mathrm{c}}$ within and across regions (Table S1 in the Supplement), and total food web length varied slightly among regions, although no west-to-east increase in food web length was evident (Figs. 5 \& 6). The central deep region was the only region with 5 TLs and had a top $\mathrm{TL}_{\mathrm{c}}$ of 5.3 (Figs. 5 \& 6; the predator/scavenger amphipod Stegocephalus sp.). All other regions were comprised of 4 TLs (Fig. 6), with the same amphipod (Stegocephalus sp.) being the top consumer in the west deep region at $\mathrm{TL}_{\mathrm{C}} 4.8$ (Table S1 in the Supplement). The shallow regions were almost identical with respect to top trophic position value: the west shallow region had a top $\mathrm{TL}_{\mathrm{c}}$

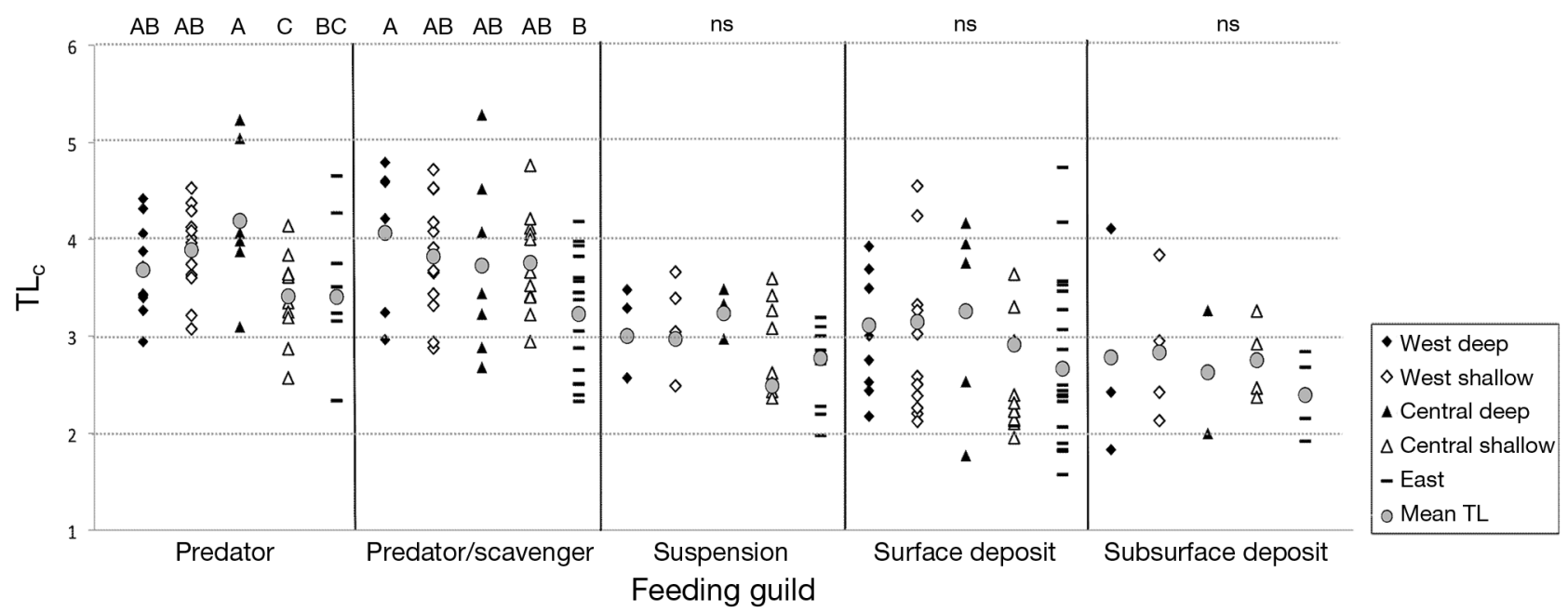

Fig. 5. Trophic level (TL) of each consumer $\left(\mathrm{TL}_{\mathrm{c}}\right)$ comprising 5 dominant feeding guilds across regions of the Alaska Beaufort Sea shelf. All TL values are standardized to regional mean $\delta^{15} \mathrm{~N}$ of sediment particulate organic matter (POM) as the baseline food source (i.e. sediment POM = TL1). Each data point represents multiple specimens of 1 species or higher taxon. Gray circles represent mean TL of all consumers within that feeding guild within a region. Different letters above data points indicate significant regional differences $(\mathrm{p}<0.05)$; ns: not significant 




Fig. 6. Trophic structure of benthic invertebrates on the Alaska Beaufort Sea shelf across regions with bulk sediment particulate organic matter (POM) as the baseline food source. Values within each bar indicate the total number of taxa in each trophic level (TL). TL1 indicates those taxa that are less than a full TL from the baseline value of regional sediment POM. Values at the top of each region bar indicate the total number of taxa collected from the respective region. WD: west deep; WS: west shallow; CD: central deep; CS: central shallow; E: east

of 4.7 (predator/scavenger Gorgonocephalus eucnemis), and the central shallow and east regions had a top $\mathrm{TL}_{\mathrm{c}}$ of 4.8 (predator/scavenger Urasterias lincki) and 4.7 (suspension-feeding Porifera and predatory sea star Crossaster papposus), respectively. Basal consumers $\left(\mathrm{TL}_{c}\right.$ closest to the POM baseline) for all regions except the west deep were suspension feeders (bivalve Liocyma fluctuosa in the west shallow; bryozoan Flustra sp. in the central deep; bivalve Hiatella arctica in the central shallow; Cumacea in the east). The subsurface deposit-feeding bivalve Yoldia hyperborea was the basal consumer in the west deep.

When consumers within feeding guilds were averaged and examined across regions, mean $\mathrm{TL}_{\mathrm{c}}$ for each feeding guild occupied in the 2 west regions were almost identical and also were similar to consumers in the central deep (Fig. 5). Consumers in the predator feeding guild occupied a significantly higher mean $\mathrm{TL}_{\mathrm{c}}$ in the central deep than this guild in the central shallow and east (ANOVA, $p=0.04$ ). Consumers in the predator/scavenger feeding guild occupied a significantly higher mean $\mathrm{TL}_{\mathrm{c}}$ in the west deep than the east (ANOVA, p = 0.03). Suspension, surface deposit, and subsurface deposit feeding guilds were highly variable, and their mean $\mathrm{TL}_{\mathrm{c}}$ were not statistically different across regions (Fig. 5). Hypothesis 4: Overall food web structure varies
among regions

Regional trophic structure in terms of relative composition of TL varied among regions and fell into 3 groups: the west deep and shallow were similar in terms of relative composition of $\mathrm{TL}$, the central deep differed from all other regions, and the central shallow and east were similar (Fig. 6). Arranging taxa into discrete TLs is not an exact representation of these food webs since taxa $\mathrm{TL}_{\mathrm{c}}$ are continuously distributed relative to the baseline sediment POM values (as shown in Fig. 5). However, this comparison may provide information regarding the relative strength of pelagic-benthic coupling among regions. Relative proportions of taxa within TLs were similar between the 2 west regions, with most taxa (>76\%) in the west shallow and deep regions occupying intermediate TLs (TL3 and TL4), with only $~ 20 \%$ of TL2 taxa and 1 TL1 taxon in the west deep. In the east and central shallow regions, taxa were generally relatively equally distributed across TL2 and TL3 $(>80 \%)$, and both regions had the same number of TL4 taxa $(n=6)$. In addition, the east region had the highest number of TL1 taxa $(n=5)$ of all regions.

Trophic structure was unique in the central deep. This region harbored the least number of taxa in the benthic community to be included in the food web study, had the lowest proportion of TL2 consumer taxa, and was also the only region with 3 consumer taxa occupying a fifth TL (Stegocephalus sp., C. papposus, and G. eucnemis).

Hypothesis 5: The trophic redundancy of consumers decreases and trophic separation increases from west to east

Our data did not support this hypothesis; trophic redundancy and separation did not follow a west-toeast gradient. Redundancy was lowest in the central deep region (NND $=1.01$ ), followed by the west deep region $(\mathrm{NND}=0.65)$, and was highest and similar in the other shallower regions $(\mathrm{NND}=0.51$ to 0.58 ; Fig. 7). CD, used as a proxy for trophic separation, had an inverse pattern to trophic redundancy. Trophic separation was highest in the central deep $(C D=3.14)$ and similar among other regions $(\mathrm{CD}=2.42$ to 2.58 ; Fig. 7). Community-wide isotopic niche space, represented as the TA occupied in regional $\delta^{13} \mathrm{C}-\delta^{15} \mathrm{~N}$ biplots, varied among regions (Fig. 7). TA was lowest in the west deep $(19 \%)$, highest in the central deep $(37 \%)$ despite the lowest number of taxa contributing 

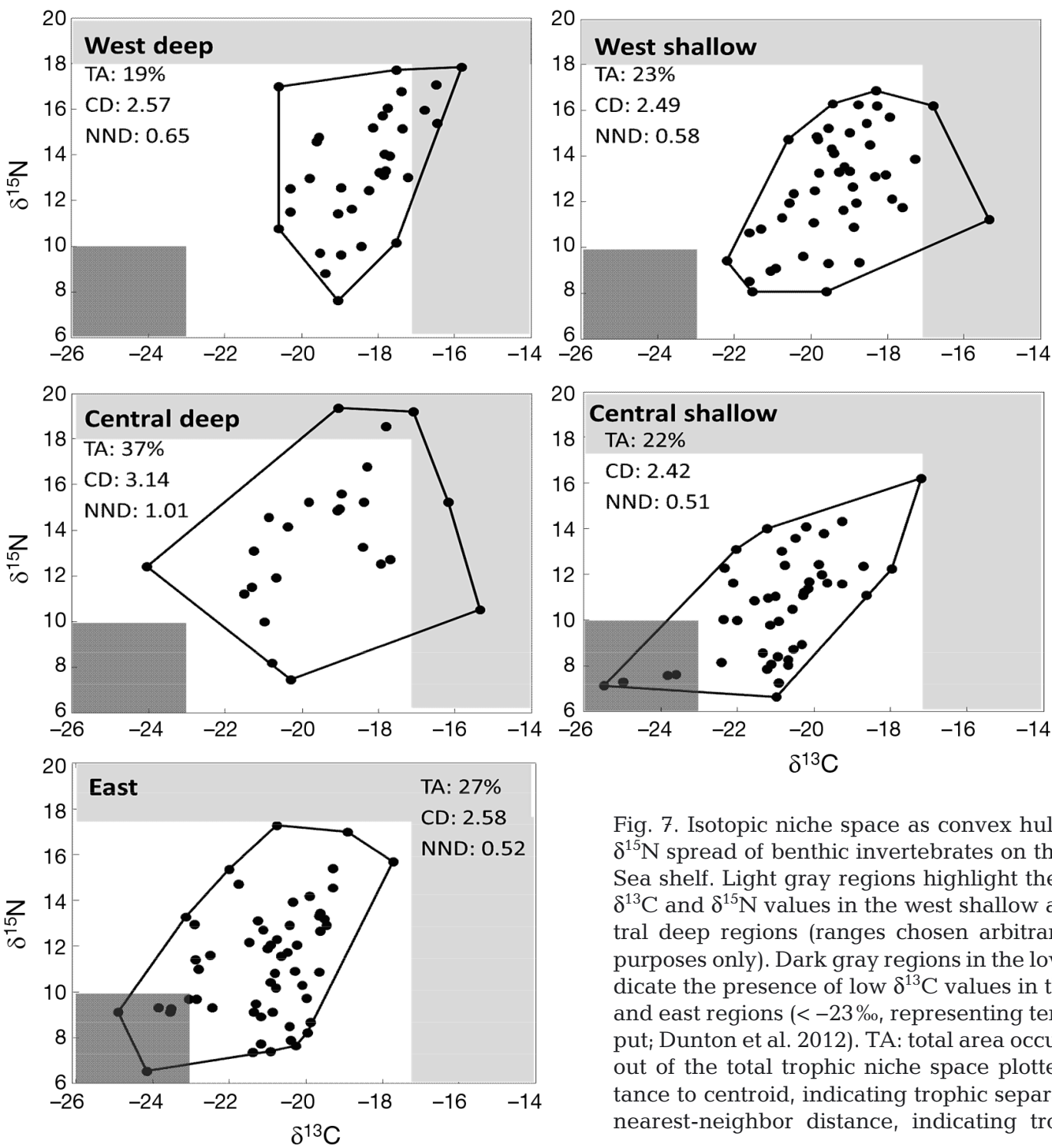

Fig. 7. Isotopic niche space as convex hulls of $\delta^{13} \mathrm{C}(\%)$ and $\delta^{15} \mathrm{~N}$ spread of benthic invertebrates on the Alaska Beaufort Sea shelf. Light gray regions highlight the presence of high $\delta^{13} \mathrm{C}$ and $\delta^{15} \mathrm{~N}$ values in the west shallow and deep and central deep regions (ranges chosen arbitrarily for illustration purposes only). Dark gray regions in the lower left corners indicate the presence of low $\delta^{13} \mathrm{C}$ values in the central shallow and east regions $(<-23 \%$, representing terrestrial carbon input; Dunton et al. 2012). TA: total area occupied by a polygon out of the total trophic niche space plotted; CD: mean distance to centroid, indicating trophic separation; NND: mean nearest-neighbor distance, indicating trophic redundancy

\section{DISCUSSION}

to the food web, and relatively similar in the other recentral deep region compared with other regions coincided with a wide spread in consumer $\delta^{13} \mathrm{C}$ values. The lowest and highest $\delta^{13} \mathrm{C}$ extremes in the central deep were occupied by the soft coral Gersemia rubiformis $(-24.1 \%)$ and the brittle star Ophiura sarsii $(-15.3 \%)$, respectively (see gray regions of Fig. 7 ); the amphipod Stegocephalus sp. (19.4\%) and the sea star C. papposus $\left(19.2 \%\right.$ ) occupied the highest $\delta^{15} \mathrm{~N}$ values (light gray regions of Fig. 7). The TAs in the central shallow and east regions were characterized by several taxa occupying the depleted carbon and nitrogen space, which was not occupied by any taxa in the other regions (Fig. 7). These taxa were mostly bryozoans, ampeliscid amphipods, and cumaceans, all of which also occurred in other regions but in isotopically more enriched space.

\section{Spatial patterns in food sources}

We hypothesized that $\delta^{13} \mathrm{C}$ values of water column POM would decrease from west to east, following a progressively higher influx of terrestrial carbon from the Colville and Mackenzie rivers. Concurrently, fewer nutrient-rich particles originating from the productive Chukchi Sea (Ashjian et al. 2005) or upwelled waters spilling through Barrow Canyon onto the western Beaufort Sea shelf (Aagaard \& Roach 1990) would reach the eastern region. Contrary to our hypothesis, we did not see an obvious influence of the Mackenzie River on water column POM in the east (Fig. 3a). This may be due to pelagic POM samples representing a short-term snapshot of POM isotopic values, which may not necessarily have a de- 
tectable terrestrial signature if circulation patterns at the time of sampling carried discharge away from the study site. Dominant circulation patterns may advect the freshwater discharge mostly farther east onto the Mackenzie shelf and Amundsen Gulf instead of westward onto the eastern and central Alaska Beaufort shelf (O'Brien et al. 2006). Alternatively, or in addition, we did not sample during the time of peak production, and diagenetic processes until the time of our sampling may have influenced the stable isotope values of POM (Lehmann et al. 2002). Regular sampling throughout the open water period (late spring through summer) as water column production occurs and is advected into the Beaufort from the Chukchi Sea is necessary to further elucidate the variability of water column POM isotopic signatures observed in these regions.

Results of our sediment POM $\delta^{13} \mathrm{C}$ analysis, in contrast, indicated consistent and measurable input of terrestrial carbon to the seafloor across much of the Beaufort Sea shelf, as reflected in $\delta^{13} \mathrm{C}$ values of mostly $\leq-24.5 \%$ (Fig. 3b). The sediment $\delta^{13} \mathrm{C}$ pattern may be interpreted as a longer-term record of the freshwater inflow delivering terrestrial matter from the Colville and other rivers to the Beaufort Sea shelf, and our results are consistent with large-scale sediment patterns in the region (Naidu et al. 2000, Dunton et al. 2012). In contrast to the patchy patterns observed in water column POM, overall sediment POM $\delta^{13} \mathrm{C}$ values were more homogeneous across the study regions, with the exception of the outer eastern Beaufort shelf, where a localized area of isotopically enriched, marine-signature carbon was observed $\left(\delta^{13} \mathrm{C}-22.5\right.$ to $-20.5 \%$ ). This patch could have resulted from deposition of local marine primary production resulting from a recent upwelling event (Pickart 2004, Pickart et al. 2011, Tremblay et al. 2011) and subsequent vertical flux of particles to the bottom. Possibly, the outer eastern region may be regularly exposed to localized hydrographic conditions that favor accumulation of marine POM in the sediment record as known from other areas on the Beaufort Sea shelf (Conlan et al. 2013). Slight sediment $\delta^{13} \mathrm{C}$ enrichment can also result from intense microbial biomass production in areas of high POM deposition (Ivanov et al. 2012) and may account for a localized region of enriched sediment carbon. Conversely, we observed low sediment POM $\delta^{13} \mathrm{C}$ values in the central shallow region (-26.4 to $-25.6 \%$ ), indicating that while sampling occurred at a time when terrestrial carbon was not detected in the water column, it was found in sediments, highlighting the long-term accumulation of terrestrial carbon in this region (Fig. 3b). Settled sea ice algae, which are typically enriched in ${ }^{13} \mathrm{C}$ over phytoplankton (Søreide et al. 2006), may also account for some of the variability observed in sediments, but we have no current knowledge of their spatial contribution across the Beaufort Sea shelf and benthic food webs.

The overall range of water column POM $\delta^{15} \mathrm{~N}$ was more than double the range of sediment POM $\delta^{15} \mathrm{~N}$ (10 and 5\%, respectively), which may reflect the longterm integration of sediment compared with water column POM. As we suggest for the east region, recent depositional events of high phytoplankton biomass may be locally detected in $\delta^{15} \mathrm{~N}$ of surface sediments. Sediment POM values can also be isotopically modulated by nitrification and denitrification processes that can vary across shelf scales (Granger et al. 2011). In the Canadian Beaufort Sea, slightly reduced sediment $\delta^{15} \mathrm{~N}$ signals compared with water column POM on the Mackenzie shelf were attributed to the inflow of terrestrial material and possibly preferential degradation of marine sources over terrestrial sources, leading to a lack of $\delta^{15} \mathrm{~N}$ enrichment in sediments under river discharge influence (Morata et al. 2008). This could be the case for our study area as well, owing to input from numerous smaller rivers across the region.

In addition to a west-east gradient, we hypothesized that there would be an offshore enrichment of carbon isotopes in water column and sediment POM and an enrichment in nitrogen isotopes in sediment POM from shallow to deeper regions of the Beaufort shelf. Enrichment offshore would be consistent with an increase in the contribution of marine-derived organic matter to the food web at offshore stations. However, overall water column surface POM $\delta^{13} \mathrm{C}$ patterns exhibited an opposite trend, with deep regions lower in $\delta^{13} \mathrm{C}$ than their shallow counterparts. The lowest water column $\delta^{13} \mathrm{C}$ POM values were found in the offshore west and central regions, and the highest were observed nearshore close to the Colville River. This latter pattern is contrary to our expectation that terrestrial material from the Colville River significantly influences the coastal regime during the time of runoff ( $\sim$ May to September, Walker \& Hudson 2003). Dunton et al. (2012) found very low suspended particle $\delta^{13} \mathrm{C}$ values, accompanied by low salinities (ranging from 10 to 25), in the Beaufort Sea coastal lagoons, which are indicative of a strong terrestrial signal resulting from the numerous small rivers discharging directly into the lagoons. Our observations of isotopically enriched water column POM in the coastal region suggest that a remnant of upwelled water may have been trapped onshore and was cap- 
tured during our snapshot sampling. Upwelling events reaching far inshore are common and have become more frequent during August and September over the past decade (S. R. Okkonen pers. comm.). In the Beaufort Sea, shelfbreak upwelling is driven predominantly by easterly winds and can persist for many days (Pickart et al. 2013). Frequent easterly winds occurred during the sampling season in August 2011 (www.ndbc.noaa.gov), which provides support for the occurrence of upwelling-favorable conditions during sampling.

Biogeochemical reworking of POM as particles sink to great depths would be expected to cause an increase in sediment $\delta^{15} \mathrm{~N}$ values deriving from the preferential release of ${ }^{14} \mathrm{~N}$ during breakdown (Parsons et al. 1989, Mintenbeck et al. 2007). Sediment $\delta^{15} \mathrm{~N}$ POM was higher at deeper than shallower sites even with a lack in corresponding increases of $\delta^{13} \mathrm{C}$, at least partially supporting our depth-related hypothesis. Overall, contrasting carbon and nitrogen isotopic signatures are possibly due to a combination of differential degradation and reworking processes and the complex and dynamic hydrographic regimes in these regions, which are still being investigated.

\section{Regional patterns in benthic food web structure}

Food web length in an ecosystem may be governed by total available energy, energy transfer efficiency, or degree of pelagic-benthic coupling within a system (e.g. Grebmeier \& McRoy 1989, Moore et al. 2004). Food web length, therefore, can be used as a proxy for identifying functional diversity, ecosystem functioning, and food web stability (Sterner et al. 1997, Post 2002, Worm et al. 2002, Steiner et al. 2005). The taxa collected during this study were the most common and dominant (by abundance and/or biomass) representatives of the regional benthic communities, and thus we consider our results a comprehensive, albeit incomplete, representation of the regional patterns of benthic trophic structure. We hypothesized that total benthic food web length would increase from west to east towards the Mackenzie River delta based on an expected weakening of pelagic-benthic coupling with increased riverine refractory material (Carmack et al. 2004, Dunton et al. 2005, 2012). However, total benthic food web lengths were largely similar among all regions with mostly 4 TLs occupied, even though the individual taxa comprising these food webs varied slightly among regions (Table S2 in the Supplement). Hence, river influence in the east does not seem to have the hypothesized effect on overall food web length. Our food web length results support previous findings that Arctic benthic shelf food webs typically contain 4 TLs based on nitrogen isotope evidence (e.g. Iken et al. 2010, Feder et al. 2011, McTigue \& Dunton 2013). Marine mammals occasionally add a fifth level (Hobson \& Welch 1992), but in our study, invertebrates occupied a fifth level only in the central deep area, which is similar to the findings of benthic food web structure in the adjacent deep Canada Basin (Iken et al. 2005). All of these taxa also occurred in other regions; hence, these extremes were not driven by species unique to the central deep region.

Although overall food web lengths were similar among regions, we detected the hypothesized differences in proportional distribution of taxa among TLs and average $\mathrm{TL}_{\mathrm{c}}$ of specific feeding guilds among some regions (Figs. 5 \& 6). These results are based on taxon presence only and not on biomass, which would represent quantitative contributions to food web structure and thus energy flow, but biomass data were not available at the taxonomic level used in the present study. While future work should include quantitative measures into food web analysis, we can infer differences in basal food sources and perhaps differences in prey availability across regions from our current results. Feeding guild-specific differences were observed at higher TLs. For example, predators occupied generally higher $\mathrm{TL}_{\mathrm{c}}$ in the central deep than in the central shallow and east regions. Given the close proximity of these regions to each other, the generally lower $\mathrm{TL}_{\mathrm{c}}$ of predators in the central shallow and east may indicate the consistent presence and assimilation of terrestrial materials (discussed in the previous sub-section) by prey organisms in these regions. The $\mathrm{TL}_{\mathrm{c}}$ of predators/scavengers in the west deep were significantly higher than those in the east region, contrasting our hypothesis of a west-to-east gradient in food web structure due to increasing freshwater input. This pattern may be due to regionally different prey spectra for predators/ scavengers, e.g. a large proportion of higher TL taxa in the west deep versus the east (Fig. 6), although the east region was not depth stratified and thus limits this comparison. Alternatively, while detrital-based benthic food webs often contain consumers with a high degree of feeding plasticity (Moore et al. 2004, Sweeting et al. 2005, North et al. 2014), selective feeding and particle quality can drive spatial differences in food webs. Regional differences in particle selectivity of suspension and deposit feeders or spatial heterogeneity in detrital particles could be manifested in the higher $\mathrm{TL}_{\mathrm{c}}$ of the predator/scavenger 
guild. Together, our results suggest that particle selectivity may occur at least in some taxa within the suspension, surface deposit, and subsurface deposit feeding guilds and possibly spatial and temporal heterogeneity of particle quality across the shelf at a finer scale than was sampled in the present study. Similar species-specific differences in deposit feeders have been found in the Bering Sea regarding reliance on fresh algal deposits, refractory material, and sediment bacteria (North et al. 2014).

In addition to patterns observed in feeding guilds, several regional patterns emerged at the level of trophic redundancy and trophic niche space. The absence of taxa in the highly depleted carbon niche space in the western regions (Fig. 7) suggests the prevalence of marine-derived labile and isotopically enriched particles from the Chukchi Sea water masses or upwelling (Weingartner et al. 1998, Pickart et al. 2011). Interestingly, this is not reflected in the sediment POM signatures, perhaps because the fauna quickly consumes and assimilates the labile POM. In contrast, lower TL consumers in the central shallow and east regions utilized a depleted (i.e. terrestrial) carbon source. These taxa in depleted isotopic space were mostly suspension feeders also common to other sampled regions where the depleted carbon sources were either not available or, perhaps more likely, not used by these consumers. Dunton et al. (2012) found similar evidence of a terrestrial carbon subsidy in the nearshore lagoons of the eastern Alaska Beaufort shelf.

The central deep region was set apart from the other regions by a larger isotopic niche space with a food web of high trophic separation and low redundancy, again resembling to some degree the adjacent deep Canada Basin food web (Iken et al. 2005). The central deep region contained the fewest taxa overall within the food web, reflecting the low benthic diversity in this region (Konar \& Ravelo 2013). The low redundancy in the central deep is likely a result of this low diversity of taxa spread across a large range of TLs. This large spread may indicate that these taxa exhibit strong resource partitioning, resulting in the lack of niche overlap. As such, the central deep may be more sensitive to natural or anthropogenic disturbances (e.g. fisheries biomass removal, oil and gas activity) than the other regions (Worm \& Duffy 2003, Layman et al. 2007). While we do not currently have information on the food web of the deep eastern Beaufort Sea, we suspect it may be similar to the central deep based on ongoing studies. It generally should be noted that our results are based on the number of taxa present in food webs and not on quantitative measures of biomass or abundance by which these taxa contribute to the food webs, as these data were not available at the same taxonomic resolution used in the present study. Relating regional food web structure described here to quantitative biomass estimates of these taxa in the various regions could provide additional trophic information.

\section{CONCLUSIONS}

As Arctic marine environments face unprecedented challenges associated with climate change, including loss of sea ice, species range extensions, and changes in the timing and intensity of primary production, establishing a baseline of energy flow and benthic food web structure for future comparisons is critical. This study increased our understanding of food webs on the Alaska Beaufort shelf by documenting the regional-scale similarities and differences in trophic structure and energy flow. Based on our findings, we suggest that different regions in the Beaufort Sea may be differentially susceptible to the effects of climatic changes. The west region food webs may be most responsive to hydrographic and oceanographic changes in the inflow of Chukchi Sea water and, consequently, the advection of nutrient-rich particles onto the western Beaufort Sea shelf. We suggest that the central Beaufort Sea shelf and upper slope may be particularly suitable for long-term monitoring, such as that conducted in the Bering and Chukchi seas by the Distributed Biological Observatory (www. arctic.noaa.gov/dbo/). The unique benthic food web characteristics in the central deep region, specifically the high trophic separation and low redundancy of consumers, make this region vulnerable to changes and may serve to provide early detection of biological response to climatic changes.

Acknowledgements. We thank the crew of the R/V 'Norseman II' for their assistance during the cruise and all cruise participants who were instrumental in sampling efforts. This study was made possible in part by samples collected under Bureau of Ocean Energy Management (BOEM) Cooperative Agreement No. M10AC2004 'Beaufort Sea Marine Fish Monitoring in the Central Beaufort Sea', US Department of the Interior, BOEM, Alaska Outer Continental Shelf Region, Anchorage, Alaska, as part of the BOEM Environmental Studies Program. The National Science Foundation Marine Ecosystem Sustainability in the Arctic and Subarctic (MESAS) Integrative Graduate Education and Research Traineeship (IGERT) program (Award DGE-0801720) provided support for L.D. Participation of K.I. and B.B. in the field survey was supported by the Coastal Marine Institute (CMI, Award M11AC00003). Stable isotope analysis was 
made possible by the North Pacific Research Board (NPRB, Award 1227) and the above CMI grant. We also thank T. Howe and N. Haubenstock of the Alaska Stable Isotope Facility for their assistance during isotope processing. We are grateful for assistance with taxonomic identifications by L. Cole (Smithsonian Institution; ascidians), K. Coyle (University of Alaska Fairbanks [UAF]; amphipods), N. Foster (NHF Consulting; mollusks), G. Hendler (Natural History Museum of Los Angeles County; ophiuroids), M. Hoberg (UAF; polychaetes), and C. Mah (Smithsonian Institution; asteroids). K. Arnoult (UAF) assisted with figures created in MATLAB. We are grateful to F. Mueter (UAF), G. Kruse (UAF), and J. Lovvorn (Southern Illinois University) for critical comments on this manuscript.

\section{LITERATURE CITED}

Aagaard K, Roach TA (1990) Arctic ocean-shelf exchange: measurements in Barrow Canyon. J Geophys Res 95: 18163-18175

Appeltans W, Bouchet P, Boxshall GA, De Broyer C and others (eds) (2012) World register of marine species (www. marinespecies.org) (accessed on 15 November 2012)

> Ashjian CJ, Gallager SM, Plourde S (2005) Transport of plankton and particles between the Chukchi and Beaufort Seas during summer 2002, described using a video plankton recorder. Deep-Sea Res II 52:3259-3280

Atkinson EG, Percy JA (1992) Diet comparison among demersal marine fish from the Canadian Artic. Polar Biol 11: 567-573

Baird D, Ulanowicz RE (1989) The seasonal dynamics of the Chesapeake Bay ecosystem. Ecol Monogr 59:329-364

Bearhop S, Adams CE, Waldrons S, Fuller RA, MacLeod H (2004) Determining trophic niche width: a novel approach using stable isotope analysis. J Anim Ecol 73: 1007-1012

> Cabana G, Rasmussen JB (1996) Comparison of aquatic food chains using nitrogen isotopes. Proc Natl Acad Sci USA 93:10844-10847

> Carmack EC, Chapman DC (2003) Wind-driven shelf/basin exchange on an Arctic shelf: the joint roles of ice cover extent and shelf-break bathymetry. Geophys Res Lett 30: 1778, doi:10.1029/2003GL017526

Carmack EC, Macdonald RW, Jasper S (2004) Phytoplankton productivity on the Canadian Shelf of the Beaufort Sea. Mar Ecol Prog Ser 277:37-50

Carroll ML, Carroll J (2003) The Arctic seas. In: Black KD, GB Shimmield (eds) Biogeochemistry of marine systems. Blackwell Publishing, Oxford, p 127-156

> Conlan K, Hendrycks E, Aitken A, Williams B, Blasco S, Crawford E (2013) Macrofaunal biomass distribution on the Canadian Beaufort Shelf. J Mar Syst 127:76-87

Cooper LW, Sexson MG, Grebmeier JM, Gradinger R, Mordy CW, Lovvorn JR (2013) Linkages between sea-ice coverage, pelagic-benthic coupling, and the distribution of spectacled eiders: observations in March 2008, 2009 and 2010, northern Bering Sea. Deep-Sea Res II 94:31-43

Dehn LA, Sheffield GG, Follmann EH, Duffy LK, Thomas DL, O'Hara TM (2007) Feeding ecology of phocid seals and some walrus in the Alaskan and Canadian Arctic as determined by stomach contents and stable isotope analysis. Polar Biol 30:167-181

Dunton K (1985) Zooplankton ${ }^{13} \mathrm{C}:{ }^{12} \mathrm{C}$ ratios in the Western Arctic Ocean: a longitudinal gradient. PhD dissertation,
University of Alaska, Fairbanks, AK

> Dunton KH, Saupe SM, Golikov AN, Schell DM, Schonberg SV (1989) Trophic relationships and isotopic gradients among arctic and subarctic marine fauna. Mar Ecol Prog Ser 56:89-97

Dunton KH, Goodall JL, Schonberg SV, Grebmeier JM, Maidment DR (2005) Multi-decadal synthesis of benthicpelagic coupling in the western Arctic: role of cross-shelf advective processes. Deep-Sea Res II 52:3462-3477

> Dunton KH, Weingartner T, Carmack EC (2006) The nearshore western Beaufort Sea ecosystem: circulation and importance of terrestrial carbon in arctic coastal food webs. Prog Oceanogr 71:362-378

> Dunton KH, Schonberg SV, Cooper LW (2012) Food-web structure of the Alaskan nearshore shelf and estuarine lagoons of the Beaufort Sea. Estuar Coast 35:416-435

ESRI (Environmental Systems Research Institute) (2011) Environmental Systems Research Institute: ArcGIS Desktop: Release 10. ESRI, Redlands, CA

Fauchald K, Jumars PA (1979) The diet of worms: a study of polychaete feeding guilds. Oceanogr Mar Biol Annu Rev 17:193-284

> Feder HM, Naidu AS, Jewett SC, Hameedi JM, Johnson WR, Whitledge TE (1994) The northeastern Chukchi Sea: benthos-environmental interactions. Mar Ecol Prog Ser 111:171-190

Feder HM, Jewett SC, Blanchard A (2005) Southeastern Chukchi Sea (Alaska) epibenthos. Polar Biol 28:402-421

Feder HM, Iken K, Blanchard AL, Jewett SC, Schonberg S (2011) Benthic food web structure in the southeastern Chukchi Sea: an assessment using $\delta^{13} \mathrm{C}$ and $\delta^{15} \mathrm{~N}$ analyses. Polar Biol 34:521-532

France RL, Peters RH (2013) Ecosystem differences in the trophic enrichment of ${ }^{13} \mathrm{C}$ in aquatic food webs. Can $\mathrm{J}$ Fish Aquat Sci 54:1255-1258

Frost KJ, Lowry LF (1983) Demersal fishes and invertebrates trawled in the northeastern Chukchi and western Beaufort Seas, 1976-1977. US Dep Comm, NOAA Tech Rep NMFS-SSRF-764

> Garneau MĖ, Vincent WF, Terrado R, Lovejoy C (2009) Importance of particle-associated bacterial heterotrophy in a coastal Arctic ecosystem. J Mar Syst 75:185-197

> Goñi MA, O'Connor AE, Kuzyk ZZ, Yunker MB, Gobeil C, Macdonald RW (2013) Distribution and sources of organic matter in surface marine sediments across the North American Arctic margin. J Geophys Res C 118:4017-4035

> Granger J, Prokopenko MG, Sigman DM, Mordy CW and others (2011) Coupled nitrification-denitrification in sediment of the eastern Bering Sea shelf leads to ${ }^{15} \mathrm{~N}$ enrichment of fixed $\mathrm{N}$ in shelf waters. J Geophys Res C 116: C11006, doi: 10.1029/2010JC006751

Grebmeier JM (2012) Shifting patterns of life in the Pacific Arctic and sub-Arctic seas. Annu Rev Mar Sci 4:63-78

Grebmeier JM, McRoy CP (1989) Pelagic-benthic coupling on the shelf of the northern Bering and Chukchi seas. III. Benthic food supply and carbon cycling. Mar Ecol Prog Ser 53:79-91

> Grebmeier JM, Cooper LW, Feder HM, Sirenko BI (2006) Ecosystem dynamics of the Pacific-influenced northern Bering and Chukchi seas in the Amerasian Arctic. Prog Oceanogr 71:331-361

Hobson KA, Welch HE (1992) Determination of trophic relationships within a high Arctic marine food web using $\delta^{13} \mathrm{C}$ and $\delta^{15} \mathrm{~N}$ analysis. Mar Ecol Prog Ser 84:9-18

Hoeinghaus DJ, Zeug SC (2008) Can stable isotope ratios 
provide for community-wide measures of trophic structure? Comment. Ecology 89:2353-2357

- Hunt GL, Stabeno PJ (2002) Climate change and the control of energy flow in the southeastern Bering Sea. Prog Oceanogr 55:5-22

Iken K, Bluhm BA, Gradinger R (2005) Food web structure in the high Arctic Canada Basin: evidence from $\delta^{13} \mathrm{C}$ and $\delta^{15} \mathrm{~N}$ analysis. Polar Biol 28:238-249

Iken K, Bluhm BA, Dunton K (2010) Benthic food-web structure under differing water mass properties in the southern Chukchi Sea. Deep-Sea Res II 57:71-85

Ivanov MV, Lein AY, Zakharova EE, Savvichev AS (2012) Carbon isotopic composition in suspended organic matter and bottom sediments of the east Arctic seas. Microbiology 81:596-605

Kaufman MR, Gradinger RR, Bluhm BA, O'Brien DM (2008) Using stable isotopes to assess carbon and nitrogen turnover in the Arctic sympagic amphipod Onisimus litoralis. Oecologia 158:11-22

Kolts JM, Lovvorn JR, North CA, Grebmeier JM, Cooper LW (2013) Relative value of stomach contents, stable isotopes, and fatty acids as diet indicators for a dominant invertebrate predator (Chionoecetes opilio) in the northern Bering Sea. J Exp Mar Biol Ecol 449:274-283

Konar B, Ravelo AM (2013) Epibenthic community variability on the Alaskan Beaufort Sea continental shelf. Final Report, OCS Study BOEM 2013-01148. Coastal Marine Institute, Fairbanks, AK

Layman CA, Arrington DA, Montaña CG, Post DM (2007) Can stable isotope ratios provide for community-wide measures of trophic structure? Ecology 88:42-48

Lehmann MF, Bernasconi SF, Barbieri A, McKenzie JA (2002) Preservation of organic matter and alteration of its carbon and nitrogen isotope composition during simulated and in situ early sedimentary diagenesis. Geochim Cosmochim Acta 66:3573-3584

> Link H, Piepenburg D, Archambault P (2013) Are hotspots always hotspots? The relationship between diversity, resource and ecosystem functions in the Arctic. PLoS ONE 8:e74077

- Logerwell EA, Rand KM, Weingartner TJ (2011) Oceanographic characteristics of the habitat of benthic fish and invertebrates in the Beaufort Sea. Polar Biol 34: 1783-1796

Lowry LF, Frost KJ, Burns JJ (2004) Bowhead whale feeding in the Alaskan Beaufort Sea, based on stomach contents analyses. J Cetacean Res Manag 6:215-223

> Macdonald RW, Falkner KK, Swift JH (1999) Connections among ice, runoff and atmospheric forcing in the Beaufort Gyre. Geophys Res Lett 26:2223-2226

Macdonald RW, Naidu AS, Yunker MB, Gobeil C (2004) The Beaufort Sea: distribution, sources, fluxes and burial of organic carbon. In: Stein R, Macdonald RW (eds) The organic carbon cycle in the Arctic Ocean. Springer, Berlin, p 177-193

> McTigue ND, Dunton KH (2013) Trophodynamics and organic matter assimilation pathways in the northeast Chukchi Sea, Alaska. Deep-Sea Res II 102:84-96

Mintenbeck K, Jacob U, Knust R, Arntz WE, Brey T (2007) Depth-dependence in stable isotope ratio $\delta^{15} \mathrm{~N}$ of benthic POM consumers: the role of particle dynamics and organism trophic guild. Deep-Sea Res II 54:1015-1023

Moore JC, Berlow EL, Coleman DC, de Ruiter PC and others (2004) Detritus, trophic dynamics and biodiversity. Ecol Lett 7:584-600
Morata N, Renaud PE, Brugel S, Hobson KA, Johnson BJ (2008) Spatial and seasonal variations in the pelagicbenthic coupling of the southeastern Beaufort Sea revealed by sedimentary biomarkers. Mar Ecol Prog Ser 371:47-63

Naidu AS (1974) Sedimentation in the Beaufort Sea: a synthesis. In: Herman Y (ed) Marine geology and oceanography of the Arctic seas. Springer, Berlin, p 173-190

- Naidu AS, Cooper LW, Finney BP, Macdonald RW, Alexander C, Semiletov IP (2000) Organic carbon isotope ratios $\left(\delta^{13} \mathrm{C}\right)$ of Arctic Amerasian continental shelf sediments. Int J Earth Sci 89:522-532

North CA, Lovvorn JR, Kolts JM, Brooks ML, Cooper LW, Grebmeier JM (2014) Deposit-feeder diets in the Bering Sea: potential effects of climatic loss of sea ice-related microalgal blooms. Ecol Appl 24:1525-1542

O'Brien MC, Macdonald RW, Melling H, Iseki K (2006) Particle fluxes and geochemistry on the Canadian Beaufort Shelf: implications for sediment transport and deposition. Cont Shelf Res 26:41-81

Okkonen SR, Ashjian CJ, Campbell RG, Maslowski W, Clement-Kinney JL, Potter R (2009) Intrusion of warm Bering/Chukchi waters onto the shelf in the western Beaufort Sea. J Geophys Res C 114:C00A11, doi:10.1029/ 2008JC004870

Okkonen SR, Ashjian CJ, Campbell RG, Clarke JT, Moore SE, Taylor KD (2011) Satellite observations of circulation features associated with a bowhead whale feeding 'hotspot' near Barrow, Alaska. Remote Sens Environ 115: 2168-2174

Parsons TR, Webb DG, Rokeby BE, Lawrence M, Hopky GE, Chiperzak DB (1989) Autotrophic and heterotrophic production in the Mackenzie River/Beaufort Sea estuary. Polar Biol 9:261-266

Pickart RS (2004) Shelfbreak circulation in the Alaskan Beaufort Sea: mean structure and variability. J Geophys Res 109 C:C04024, doi:10.1029/2003JC001912

Pickart RS, Spall MA, Moore GWK, Weingartner TJ, Woodgate RA, Aagaard K, Shimada K (2011) Upwelling in the Alaskan Beaufort Sea: atmospheric forcing and local versus non-local response. Prog Oceanogr 88:78-100

> Pickart RS, Schulze LM, Moore GWK, Charette MA, Arrigo KR, van Dijken G, Danielson SL (2013) Long-term trends of upwelling and impacts on primary productivity in the Alaskan Beaufort Sea. Deep-Sea Res I 79:106-121

Post DM (2002) Using stable isotopes to estimate trophic position: models, methods, and assumptions. Ecology 83: 703-718

Rachold V, Eicken H, Gordeev VV, Grigoriev MN and others (2004) Modern terrigenous organic carbon input to the Arctic Ocean. In: Stein R, Macdonald RW (eds) The organic carbon cycle in the Arctic Ocean. Springer, Berlin, p 33-55

- Rand KM, Logerwell EA (2011) The first demersal trawl survey of benthic fish and invertebrates in the Beaufort Sea since the late 1970s. Polar Biol 34:475-488

Rau GH, Sullivan CW, Gordon LI (1991) $\delta^{13} \mathrm{C}$ and $\delta^{15} \mathrm{~N}$ variations in Weddell Sea particulate organic matter. Mar Chem 35:355-369

Sampei M, Sasaki H, Hattori H, Forest A, Fortier L (2009) Significant contribution of passively sinking copepods to the downward export flux in Arctic waters. Limnol Oceanogr 54:1894-1900

Saupe SM, Schell DM, Griffiths WB (1989) Carbon-isotope ratio gradients in western arctic zooplankton. Mar Biol 103:427-432 
Schell DM, Saupe SM, Haubenstock N (1989) Bowhead whale (Balaena mysticetus) growth and feeding as estimated by $\delta^{13} \mathrm{C}$ techniques. Mar Biol 103:433-443

Schell DM, Barnett BA, Vinette KA (1998) Carbon and nitrogen isotope ratios in zooplankton of the Bering, Chukchi and Beaufort seas. Mar Ecol Prog Ser 162:11-23

Sholto-Douglas AD, Field JG, James AG, van der Merwe NJ (1991) ${ }^{13} \mathrm{C} /{ }^{12} \mathrm{C}$ and ${ }^{15} \mathrm{~N} /{ }^{14} \mathrm{~N}$ isotope ratios in the Southern Benguela Ecosystem: indicators of food web relationships in different size-classes of plankton and pelagic fish; differences between fish muscle and bone collagen tissues. Mar Ecol Prog Ser 78:23-31

Søreide JE, Hop H, Carroll ML, Falk-Petersen S, Hegseth EN (2006) Seasonal food web structures and sympagicpelagic coupling in the European Arctic revealed by stable isotopes and a two-source food web model. Prog Oceanogr 71:59-87

Steiner CF, Long ZT, Krumins JA, Morin PJ (2005) Temporal stability of aquatic food webs: partitioning the effects of species diversity, species composition and enrichment. Ecol Lett 8:819-828

Sterner RW, Bajpai A, Adams T (1997) The enigma of food chain length: absence of theoretical evidence for dynamic constraints. Ecology 78:2258-2262

Sweeting CJ, Jennings S, Polunin NVC (2005) Variance in isotopic signatures as a descriptor of tissue turnover and degree of omnivory. Funct Ecol 19:777-784

Tamelander T, Søreide JE, Hop H, Carroll ML (2006) Fractionation of stable isotopes in the Arctic marine copepod Calanus glacialis: effects on the isotopic composition of marine particulate organic matter. J Exp Mar Biol Ecol 333:231-240

Thornton SF, McManus J (1994) Application of organic carbon and nitrogen stable isotope and $\mathrm{C} / \mathrm{N}$ ratios as source indicators of organic matter provenance in estuarine sys- tems: evidence from Tay Estuary, Scotland. Estuar Coast Shelf Sci 38:219-233

Tremblay JÉ, Bélanger S, Barber DG, Asplin M and others (2011) Climate forcing multiplies biological productivity in the coastal Arctic Ocean. Geophys Res Lett 38:L18604, doi:10.1029/2011GL048825

> Vander Zanden MJ, Rasmussen JB (2001) Variation in $\delta^{15} \mathrm{~N}$ and $\delta{ }^{13} \mathrm{C}$ trophic fractionation: implications for aquatic food web studies. Limnol Oceanogr 46:2061-2066

> Vander Zanden MJ, Cabana G, Rasmussen JB (1997) Comparing trophic position of freshwater fish calculated using stable nitrogen isotope ratios $\left(\delta^{15} \mathrm{~N}\right)$ and literature dietary data. Can J Fish Aquat Sci 54:1142-1158

Walker HJ, Hudson PF (2003) Hydrologic and geomorphic processes in the Colville River delta, Alaska. Geomorphology 56:291-303

> Weems J, Iken K, Gradinger R, Wooller MJ (2012) Carbon and nitrogen assimilation in the Bering Sea clams Nuculana radiata and Macoma moesta. J Exp Mar Biol Ecol 430-431:32-42

Weingartner TJ (2008) Physical oceanography. In: Hopcroft R, Bluhm B, Gradinger R (eds) Arctic Ocean synthesis: analysis of climate change impacts in the Chukchi and Beaufort Seas with strategies for future research. Institute of Marine Sciences, University of Alaska, Fairbanks, p 6-17

Weingartner TJ, Cavalieri MD, Aagaard K, Sasaki Y (1998) Circulation, dense water formation and outflow on the northeast Chukchi shelf. J Geophys Res C 103: 7647-7662

Worm B, Duffy JE (2003) Biodiversity, productivity and stability in real food webs. Trends Ecol Evol 18:628-632

> Worm B, Lotze HK, Hillebrand H, Sommer U (2002) Consumer versus resource control of species diversity and ecosystem functioning. Nature 417:848-851

Submitted: November 5, 2014; Accepted: May 11, 2015

Proofs received from author(s): June 24, 2015
Editorial responsibility: Katherine Richardson, Copenhagen, Denmark 